\title{
Glycemia in spontaneous intracerebral hemorrhage: clinical implications
}

\author{
Hernando Alvis-Miranda ${ }^{1}$, Gabriel Alcala-Cerra ${ }^{2}$, Luis Rafael \\ Moscote-Salazar ${ }^{2}$
}

Universidad Cartagena, Colombia

${ }^{1}$ Cartagena de Indias; ${ }^{2}$ Neurosurgeon

\begin{abstract}
Spontaneous cerebral hemorrhage or intracranial hemorrhage accounts for $10-15 \%$ of all strokes. Intracranial hemorrhage is much less common than ischemic stroke, but has higher mortality and morbidity, one of the leading causes of severe disability. Various alterations, among these the endocrine were identified when an intracerebral hemorrhage, these stress-mediated mechanisms exacerbate secondary injury. Deep knowledge of the injuries which are directly involved alterations of glucose, offers insight as cytotoxicity, neuronal death and metabolic dysregulations alter the prognosis of patients with spontaneous intracerebral hemorrhage.
\end{abstract}

Key words: intracranial hemorrhage, Glycemia, stroke, neurosurgery

\section{Introduction}

Spontaneous intracerebral hemorrhage (sICH) is a devastating and disabling disease $(1,2)$. Is the second most common form of stroke, representing $10-30 \%$ of first-ever strokes (3). Overall incidence sICH worldwide is 24.6 per 100,000 person-years with approximately 40,000 to 67,000 cases per year in the United States (4-7), approximately half of this mortality occurs within the first 24 hours, highlighting the critical importance of early and effective treatment in EDs (8).

Deleterious effect of metabolic derangements like hyperglycemia has been studied since Claude Bernard described the relationship between hyperglycemia and cerebral injury (9). The occurrence of hyperglycemia is a known phenomenon in various types of acute cerebral injury. When measured at arrival to $\mathrm{ED}$, hyperglycemia is associated with worse outcome in both diabetic and nondiabetic patients (10-13).

A high proportion of patients (about 60\%) might develop hyperglycemia even in the absence of a previous history of diabetes after sICH (14). Increased blood glucose in the acute setting of sICH is probably a response to stress and severity of sICH (15) and can persist for up to $72 \mathrm{~h}$ after sICH (14). Declining glucose values after sICH are associated with a decreased risk of hematoma expansion and poor outcome, suggesting that early glucose 
control may improve outcomes (16). Many studies have shown that increased serum glucose on admission is associated with larger haematoma size, expantion, perihematomal oedema, cell death, intraventricular extention (17), and increased risk of poor outcome (10, $11,14,18,19)$, furthermore is a potent predictor of 30 day mortality in both diabetic and non-diabetic patients with $\mathrm{sICH}$ as well as an independent predictor of early mortality and worse functional outcome in non-diabetic patients with $\operatorname{sICH}(11,19,20)$.

\section{Glucose and brain physiology (21-48)}

The brain is an expensive energy organ. Brain function requires the $15 \%$ of the cardiac output, consumes $20 \%$ of the oxygen and the $25 \%$ of the total organism glucose; has a high tolerance to the temporal fuel deficit, because it only consumes approximately $33 \%$ of the available oxygen and a $10 \%$ of the total glucose. The cerebral blood flow (CBF) is the supply of energetic sources, in a mean of $50 \mathrm{~mL} / 100 \mathrm{~g} / \mathrm{min}$, with a brain oxygen consumption of $50 \mathrm{~cm} 3 / \mathrm{min}$, and a similar carbon dioxide production, with a respiratory quotient near to 1 , indicating that carbohydrates are the main substrates for the brain oxidative metabolism (49).

All the different cells types in the central nervous system (i.e., neurons, glia and vascular cells) show a different metabolic glucose consumption rate. Virtually, the only metabolic fuel of the brain is glucose; under aerobic conditions this molecule undergoes glycolysis to adenosine triphosphate (ATP) and pyruvate. Pyruvate is converted to acetylCoA via the Kreb's cycle to generate ATP and reducing equivalents, this is the aerobic way, renders 30 moles of ATP; exists another way to convert glucose to ATP, the anaerobic way, but it is inefficient, just renders 2 moles of ATP through production of lactic acid.

Glucose entre to the brain through GLUT family of hexose transportes; astrocytes express GLUT1, GLUT2, and GLUT4, neurons express GLUT3, GLUT4, and GLUT8 (50). If neurons, preferentially access to glucose directly from the brain interstitial fluid or if the metabolism of glucose to lactate by astrocytes is a required step, is still in debate $(51,52)$.

Brain needs glucose, but also controls the glucose levels when integrating information from peripheral receptors (53). Has been established that brain insulin plays a crucial role in the regulation of the metabolism, enhancing glucose uptake by astrocytes (54). Studies using SPECT technology have suggested that glucose transport and metabolism in human brain are dependent of blood supply. Has been demonstrated insulinmediated increases in mean global rate of brain glucose utilization, suggesting that insulin may play some role in the regulation of cerebral glucose, especially in the cortex (55).

Alterations of the insulin actions in the brain are involved in metabolic diseases. The mechanisms by which glucose sensitive neurons detect changes in glycemia and alter their firing pattern are still being investigated. In the glucose sensing process participate the same proteins that control glucose signaling in pancreatic beta-cells (56), i.e., the GLUT2, the enzyme glucokinase and the ATP sensitive potassium channel. In the response to 
DOI: 10.2478/romneu-2014-0043

hypoglycemia participate the AMP-activated protein kinase (57).

When an injury impaired the oxidative phosphorylation, either lower arterial oxygen tension, mitochondrial dysfunction or brain lesions, the glycolysis is deviated to the anaerobic way, producing lactic acid and hydrogen ions, generating tissue acidosis and reactive species of oxygen, respectively. When this takes place, trigger deleterious effects in the neuronal cells, product of the activation of calcium entry to the cells, the release of cytotoxic free fatty acids and excitotoxic neurotransmitters like glutamate. Although the intermediate metabolites of glucose breakdown, pyruvate and lactate, in some circumstances can sustain the energy demand of the neuronal activity, both lack the ability to cross the blood-brain barrier. In pathological states, also are used as metabolic substrates the ketonic bodies.

Brain glycogen is primarily located in the astrocytes (58). And its stores finishes in about 5 minutes, when needed. In an animal model of type 2 diabetes mellitus, glycogen metabolism has been demonstrated to be important for supporting glutamatergic and GABAergic homeostasis, maintaining a proper ratio between excitatory and inhibitory neurotransmitters (59). Different animal and human studies evidence a significantly compromised altered glucose metabolism in the setting of traumatic brain injury, cerebral ischemia and hemorrhages. Due to the mitochondrial membrane dysfunction during hypoxic and hyperglycemic insults, the cells in the perihemorrhagic area are unable to metabolise the excess of glucose, this happens specifically in intracerebral hemorrhage, and are the main phenomena to comprehend why hypo/hyperglycemia are so deleterious in the setting of an acute brain lesion.

\section{Hyperglycemia and the sICH}

The hyperglycemic state results from metabolic derangements in the glucose metabolism (60). In the acute phase of sICH develops an unspecific, programmed and adaptive response to the stress that induce activation of the hypothalamic-hypophysisadrenal axis and the subsequent releasing of hyperglycemic hormones (61-64), activation of the autonomous nervous system and changes in the behavior, everything as a part of the well described metabolic-hormonal response to stress and to the systemic inflammatory response syndrome (SIRS).

In the context of a lesion, irrespective of the nature, the mechanism that drives to a stress hyperglycemia are the increased gluconeogenesis and insulin resistance, the later, may be result from impaired insulin receptor binding and signal transduction, increased hepatic glucose production, and decreased peripheral glucose uptake (65).

The big final effect, a stress-induced hyperglycemic state, constitutes an aggravating factor of the lesion. Also has been demonstrated an independent relationship between the kind and the severity of the neurologic injury $(66,67)$. The surgical procedures also contribute to activate a neuroendocrine response that predispose the patient to develop hyperglycemia and ketoacidosis because its antagonizing action on the insulin activity $(60,63)$. Other well 
documented effects of stress-induced hyperglycemia are the endothelial cell dysfunction, increased oxidative stress, cardiovascular effects and lesion in other specific brain areas (68-70).

When the hyperglycemic state is stablished, it plays a range of deleterious mechanisms on the injured brain, through the increase of oxidative stress, inflammatory cytokines, induction of excitotoxicity [e.g., stimulation of the N-methyl-Daspartate (NMDA) receptor] potentiating the calcium entry to the cells, alters the brain metabolism and therefore the perfusion (71-73). Due to the above, glucose neurotoxicity

The excessive glucose concentration in the lesions microenvironment induces lipid peroxidation, protein carbonilation, and DNA damage. As the superoxyde is been neutralizing the nitric oxide, the vasodilation is impaired $(74,75)$. As result of the productions of reactive species of oxygen (RSO), then is activated an inflammatory response that leads to immune cells attraction, and then increasing the production of EROs. Lactic acid is also concentrated, so is an easy way to turn acidotic the neuron cells, this acidosis alters mitochondrial function $(76,77)$.

In rat models of intracerebral hemorrhage (78-80) have been demonstrated the mentioned physiopathological events, and higher size of hemorrhage in the hyperglycemic rat groups. In a recent experiment was observed that in response to the intracerebral hemorrhage lesion, significant increase of albumin was ubiquitously observed in the brains of normoglycemic rats but not in the brains of hyperglycemic rats. In the last group, more significant neuronal apoptosis were found in the perihematomal regions of hyperglycemic rats, suggesting a protection role of albumin in acute stage of intracerebral hemorrhage, which may be dependent on different blood sugar levels (81).

\section{Hypoglucemia and the sCHI}

Defined as glucose plasma level $<50 \mathrm{mg} / \mathrm{dL}$ $(<2.8 \mathrm{mmol} / \mathrm{L})$ with/without symptoms (49). Currently, there is a paucity of data on cerebral glucose metabolism in human subjects with spontaneous intracerebral hemorrhage, but have been demonstrated that hypoglycemia, the other side of the coin, also worsens the outcome of patients with critical illness. In the acute injured brain, hypoglycemia could be particularly harmful.

The "neurological injury glucose threshold" varies with some patient's factors, i.e., history of diabetes mellitus, the speed of the glucose level drop, the duration of the hypoglycemia event and the cerebral blood flow, etc. In patients with poor-grade subarachnoid hemorrhage the acute reductions in serum glucose, even to levels within the normal range, could generate brain energy metabolic crisis and lactate/pyruvate ratio elevation (82). When the brain's metabolism autoregulation is altered, there ares parts of them specially more susceptible than others (83-86), when could be thoughtful glucose level as "sufficient" in a patient whith acute brain lesion this might be insuffient and even deleterious. The brain's compensation systems (release of conter-regulatory hormones, increase the cerebral blood flow, use of the glycogen storages) to the glycopenia 
DOI: 10.2478/romneu-2014-0043

are limited (87-89). The big problem with a hypoglycemia state is that is associated with aberrant depolarization in the perilesional tissue that drives to a perpetuating glucose depletion, as has been demonstrated in traumatic brain injury $(32,90)$

\section{Mortality and other Outcomes}

As stated in other items of this review, the hyperglycemia measured in peripheral blood is both a marker of injury severity and of poor outcome, a relationship that has captured the attention of clinicians over the past few years. Studies evaluating the association of glycemia derangements and sICH are scarce $(10,14)$, in comparison with other types of stroke, where later researches utilize multimodal neuromonitoring with intracerebral microdialysis catheters, brain oxygen monitors and measurements of both, peripheral and cerebral blood glucose.

Kimura and colleagues with a prospective observational study design and 100 patients with acute supratentorial Intracerebral hemorrhage, assessing clinical characteristics and plasma glucose. ICH volume was measured on admission CT (b24 h) and follow-up CT (b48 h) scans. Patients were divided into two groups: the death group, who died within 14 days of onset, and the survival group. Using receiver operating characteristic (ROC) curve, founded that cut-off values that predicted early death were $150 \mathrm{mg} / \mathrm{dl}$ for the glucose level and $\mathrm{N} 20 \mathrm{ml}$ for the initial IVH volume, they conclude that admission hyperglycemia may independently increase the risk of early death in acute spontaneous intracerebral hemorrhage (10).
Godoy and collegues in a prospective study with 250 patients with a well-defined diagnosis of sICH admitted into $24 \mathrm{~h}$ in three primary referred centers. Patients had extensive monitoring of BG values and those with $B G$ values $>8.29 \mathrm{mmol} / \mathrm{l}(150 \mathrm{mg} / \mathrm{dl})$ received a variable intravenous insulin dose to maintain BG concentrations during the first $72 \mathrm{~h}$ after sICH between 3.32 and8.29 mmol/l (60-150 $\mathrm{mg} / \mathrm{dl}$ ) using pre-specified insulin dosing schedule protocol, and using a cutoff value of $>164 \mathrm{mg} / \mathrm{dL}$, they conclude that hyperglycemia is a common condition after sICH that could worsen prognosis and the very early insulin therapy does not improve prognosis, also show an increased risk of poor outcomes and death.

Stress hyperglycaemia is a common finding in patients presenting with intracerebral haemorrhage. It is a marker of poor outcomes and higher mortality, more so in patients with no known history of diabetes (91). Over the years ICH has been reported to have a mortality rate between $35-52 \%$ and poor functional outcome of survivors, with only $10-$ $20 \%$ living independently at 30 days (92-96) Literature has reported Glasgow Coma Scale (GCS) on arrival, blood pressure on presentation, volume of hemorrhage, concomitant intraventricular hemorrhage, previous ischemic stroke, and National Institutes of Health Stroke Scale (NIHSS) score as predictors of early mortality in patients with ICH (11).

For evaluating glycaemia derangements in unspecific medical conditions but in critically ill patients a study look for evaluate the compared risk adjusted mortality when those patients were admitted to a surgical intensive 
care over 4 years. Patients were divided into glycemic groups: HYPER ( $\geq 1$ episode $>180$ $\mathrm{mg} / \mathrm{dL}$, any $<60)$, HYPO $(\geq 1$ episode $<60$ $\mathrm{mg} / \mathrm{dL}$, any $>180$ ), BOTH ( $\geq 1$ episode $<60$ and $\geq 1$ episode $>180 \mathrm{mg} / \mathrm{dL}$ ), NORMO (all episodes 60-180 mg/dL), HYPER-Only ( $\geq 1$ episode $>180$, none $<60 \mathrm{mg} / \mathrm{dL}$ ), and HYPOOnly ( $\geq$ episode $<60$, none $>180 \mathrm{mg} / \mathrm{dL}$ ). The mortality ratios $(\mathrm{O} / \mathrm{E})$ were studied using the expected Acute Physiology and Chronic Health Evaluation (APACHE) III. Number of adverse glycemic events was compared with mortality. Hypoglycemia and hyperglycemia occurred in 18 per cent and 50 per cent of patients. Mortality was 12.4 per cent $(\mathrm{O} / \mathrm{E}=$ $0.88)$. BOTH had the highest $\mathrm{O} / \mathrm{E}$ ratio (1.43) with HYPO the second highest (1.30). Groups excluding hypoglycemia (NORMO and HYPER-only) had the lowest O/E ratios: 0.56 and 0.88 . Increasing number of hypoglycemic events were associated with increasing $\mathrm{O} / \mathrm{E}$ ratio: $0.69 \mathrm{O} / \mathrm{E}$ for no events, 1.19 for $1-3$ events, 1.35 for 4-6 events, 1.9 for 7-9 events, and 3.13 for $>/=10$ events. As result was observed that, ten or more hyperglycemic events were needed to significantly associate with worse mortality (O/E 1.53); and hyper/hypoglycemia increase mortality compared with APACHE III expected mortality, with highest mortality risk if both are present. In this study hypoglycemia was associated with worse risk, so the authors recommend that glucose control may need to be loosened to prevent hypoglycemia and reduce glucose variability (97).

In a study evaluating the prognosis and outcome of acute stroke in an Universitary hospital in Nigeria, founded that age above 39 years, male gender, systemic hypertension, early onset of coma after stroke, and presence of co-morbidities were associated with poor stroke outcome, the $78.8 \%$ of all stroke subtypes corresponded to intracerebral hemorrhage (98).

The effects of parameters as elevation of white blood cell count (WBC), C-reactive protein (CRP), and blood glucose (BG) concentration at presentation prognosticate poor outcome in sICH patients were investigated for Di Napoli and colleagues conclude that higher WBC, CRP, and BG are associated with increased mortality in sICH patients, and also founded that only CRP elevation portends higher risk of death independently of other indicators of sICH severity (99).

In the Acute Brain Bleeding Analysis Study, a korean study for evaluate the effects of glucose level on early and long-term mortality after intracerebral haemorrhage was observed a long-term mortality rate of $21.1 \%$ after a mean follow-up of $434.3+/-223.2$ days and was found to increase significantly with glucose quartile $(\mathrm{p}<0.001)$. The admission glucose level was an independent risk factor for early mortality (adjusted HR 1.10 [95\% CI 1.01-1.19]), but not for long-term mortality. Moreover, when analysis was restricted to patients without diabetes, glucose level was found to be an independent risk factor for post-ICH mortality $(\mathrm{n}=1,119$; adjusted HR 1.10 [95\% CI 1.03-1.17]) and had marginal significance for early $(\mathrm{p}=0.053)$ and longterm mortality $(p=0.09)$. From the above is conclusive that admission glucose levels are associated with early mortality after 
DOI: 10.2478/romneu-2014-0043

intracerebral hemorrhage. In patients without diabetes, admission glucose levels were associated with long-term mortality (19).

Kimura and colleagues have founded an association between hyperglycemia at admission to EDs and an increased risk of early death (10). Other worry about the assessment of mortality in sICH is that in comparison with other cerebrovascular diseases, there are no grading prognostic scales routinely used in sICH around the world.

\section{Correspondence}

Dr. Luis Rafael Moscote-Salazar, Universidad de Cartagena, Cartagena de Indias, Colombia. E-mail: mineurocirujano@aol.com

\section{References}

1.Qureshi AI, Tuhrim S, Broderick JP, Batjer HH, Hondo $\mathrm{H}$, Hanley DF. Spontaneous intracerebral hemorrhage. The New England journal of medicine. 2001 May 10;344(19):1450-60. PubMed PMID: 11346811. Epub 2001/05/11. eng.

2.Flaherty ML, Haverbusch M, Sekar P, Kissela B, Kleindorfer D, Moomaw CJ, et al. Long-term mortality after intracerebral hemorrhage. Neurology. 2006 Apr 25;66(8):1182-6. PubMed PMID: 16636234. Epub 2006/04/26. eng.

3.Balami JS, Buchan AM. Complications of intracerebral haemorrhage. The Lancet Neurology. 2012;11(1):101-18. 4.Aguilar MI, Freeman WD. Spontaneous intracerebral hemorrhage. Seminars in neurology. 2010 Nov;30(5):55564. PubMed PMID: 21207348. Epub 2011/01/06. eng. 5.Broderick J, Connolly S, Feldmann E, Hanley D, Kase C, Krieger D, et al. Guidelines for the management of spontaneous intracerebral hemorrhage in adults: 2007 update: a guideline from the American Heart Association/American Stroke Association Stroke Council, High Blood Pressure Research Council, and the Quality of Care and Outcomes in Research Interdisciplinary Working Group. Circulation. 2007 Oct 16;116(16):e391-413. PubMed PMID: 17938297. Epub 2007/10/17. eng.
6.Broderick JP, Brott T, Tomsick T, Miller R, Huster G. Intracerebral hemorrhage more than twice as common as subarachnoid hemorrhage. Journal of neurosurgery. 1993 Feb;78(2):188-91. PubMed PMID: 8421201. Epub 1993/02/01. eng.

7.van Asch CJ, Luitse MJ, Rinkel GJ, van der Tweel I, Algra A, Klijn CJ. Incidence, case fatality, and functional outcome of intracerebral haemorrhage over time, according to age, sex, and ethnic origin: a systematic review and meta-analysis. Lancet neurology. 2010 Feb;9(2):167-76. PubMed PMID: 20056489. Epub 2010/01/09. eng.

8.Elliott J, Smith M. The acute management of intracerebral hemorrhage: a clinical review. Anesthesia and analgesia. 2010 May 1;110(5):1419-27. PubMed PMID: 20332192. Epub 2010/03/25. eng.

9.Berard C. Chives rendus diabétiques. CR Soc Bilo (Paris). 1849;1:10.

10.Kimura K, Iguchi Y, Inoue T, Shibazaki K, Matsumoto $\mathrm{N}$, Kobayashi $\mathrm{K}$, et al. Hyperglycemia independently increases the risk of early death in acute spontaneous intracerebral hemorrhage. Journal of the neurological sciences. 2007 Apr 15;255(1-2):90-4. PubMed PMID: 17350046.

11.Stead LG, Jain A, Bellolio MF, Odufuye A, Gilmore RM, Rabinstein A, et al. Emergency Department hyperglycemia as a predictor of early mortality and worse functional outcome after intracerebral hemorrhage. Neurocritical care. 2010 Aug;13(1):67-74. PubMed PMID: 20390379. Epub 2010/04/15. eng.

12.Alberti $\mathrm{O}$, Becker $\mathrm{R}$, Benes $\mathrm{L}$, Wallenfang $\mathrm{T}$, Bertalanffy $\mathrm{H}$. Initial hyperglycemia as an indicator of severity of the ictus in poor-grade patients with spontaneous subarachnoid hemorrhage. Clinical neurology and neurosurgery. 2000 Jun;102(2):78-83. PubMed PMID: 10817893. Epub 2000/05/19. eng.

13.Passero S, Ciacci G, Ulivelli M. The influence of diabetes and hyperglycemia on clinical course after intracerebral hemorrhage. Neurology. 2003 Nov 25;61(10):1351-6. PubMed PMID: 14638954. Epub 2003/11/26. eng.

14.Godoy DA, Pinero GR, Svampa S, Papa F, Di Napoli M. Hyperglycemia and short-term outcome in patients with spontaneous intracerebral hemorrhage. Neurocritical care. 2008;9(2):217-29. PubMed PMID: 18300001. 
15.Fogelholm R, Murros K, Rissanen A, Avikainen S. Admission blood glucose and short term survival in primary intracerebral haemorrhage: a population based study. Journal of neurology, neurosurgery, and psychiatry. 2005 Mar;76(3):349-53. PubMed PMID: 15716524. Pubmed Central PMCID: PMC1739544. Epub 2005/02/18. eng.

16.Anderson CS, Huang Y, Arima H, Heeley E, Skulina C, Parsons MW, et al. Effects of early intensive blood pressure-lowering treatment on the growth of hematoma and perihematomal edema in acute intracerebral hemorrhage: the Intensive Blood Pressure Reduction in Acute Cerebral Haemorrhage Trial (INTERACT). Stroke; a journal of cerebral circulation. 2010 Feb;41(2):307-12. PubMed PMID: 20044534. Epub 2010/01/02. eng.

17.Appelboom G, Piazza MA, Hwang BY, Carpenter A, Bruce SS, Mayer S, et al. Severity of intraventricular extension correlates with level of admission glucose after intracerebral hemorrhage. Stroke; a journal of cerebral circulation. 2011 Jul;42(7):1883-8. PubMed PMID: 21636822. Epub 2011/06/04. eng.

18. Broderick JP, Diringer MN, Hill MD, Brun NC, Mayer $\mathrm{SA}$, Steiner $\mathrm{T}$, et al. Determinants of intracerebral hemorrhage growth: an exploratory analysis. Stroke; a journal of cerebral circulation. 2007 Mar;38(3):1072-5. PubMed PMID: 17290026. Epub 2007/02/10. eng.

19.Lee SH, Kim BJ, Bae HJ, Lee JS, Lee J, Park BJ, et al. Effects of glucose level on early and long-term mortality after intracerebral haemorrhage: the Acute Brain Bleeding Analysis Study. Diabetologia. 2010 Mar;53(3):429-34. PubMed PMID: 20091021. Epub 2010/01/22. eng.

20.Bejot Y, Aboa-Eboule C, Hervieu M, Jacquin A, Osseby GV, Rouaud O, et al. The deleterious effect of admission hyperglycemia on survival and functional outcome in patients with intracerebral hemorrhage. Stroke; a journal of cerebral circulation. 2012 Jan;43(1):243-5. PubMed PMID: 21940959. Epub 2011/09/24. eng.

21.Bullock R, Zauner A, Woodward JJ, Myseros J, Choi SC, Ward JD, et al. Factors affecting excitatory amino acid release following severe human head injury. Journal of neurosurgery. 1998 Oct;89(4):507-18. PubMed PMID: 9761042. Epub 1998/10/07. eng.

22.De Salles AA, Muizelaar JP, Young HF. Hyperglycemia, cerebrospinal fluid lactic acidosis, and cerebral blood flow in severely head-injured patients.
Neurosurgery. 1987 Jul;21(1):45-50. PubMed PMID: 3614603. Epub 1987/07/01. eng.

23.Frykholm P, Andersson JL, Langstrom B, Persson L, Enblad P. Haemodynamic and metabolic disturbances in the acute stage of subarachnoid haemorrhage demonstrated by PET. Acta neurologica Scandinavica. 2004 Jan;109(1):25-32. PubMed PMID: 14653847.

24.Harris JJ, Attwell D. The energetics of CNS white matter. The Journal of neuroscience : the official journal of the Society for Neuroscience. 2012 Jan 4;32(1):356-71. PubMed PMID: 22219296. Pubmed Central PMCID: 3272449.

25.He Y, Liu W, Koch LG, Britton SL, Keep RF, Xi G, et al. Susceptibility to intracerebral hemorrhage-induced brain injury segregates with low aerobic capacity in rats. Neurobiology of disease. 2012 Aug 24;49C:22-8. PubMed PMID: 22939993.

26. Hertz L. Bioenergetics of cerebral ischemia: a cellular perspective. Neuropharmacology. 2008 Sep;55(3):289309. PubMed PMID: 18639906.

27.Illanes S, Liesz A, Sun L, Dalpke A, Zorn M, Veltkamp R. Hematoma size as major modulator of the cellular immune system after experimental intracerebral hemorrhage. Neuroscience letters. 2011 Mar 3;490(3):170-4. PubMed PMID: 21130839.

28. Kawamura S, Sayama I, Yasui N, Uemura K. Sequential changes in cerebral blood flow and metabolism in patients with subarachnoid haemorrhage. Acta neurochirurgica. 1992;114(1-2):12-5. PubMed PMID: 1561932.

29.Kinoshita K, Moriya T, Utagawa A, Sakurai A, Mukoyama T, Furukawa M, et al. Change in brain glucose after enteral nutrition in subarachnoid hemorrhage. The Journal of surgical research. 2010 Aug;162(2):221-4. PubMed PMID: 19815233.

30.Marsh WR, Anderson RE, Sundt TM, Jr. Effect of hyperglycemia on brain $\mathrm{pH}$ levels in areas of focal incomplete cerebral ischemia in monkeys. Journal of neurosurgery. 1986 Nov;65(5):693-6. PubMed PMID: 3772458. Epub 1986/11/01. eng.

31.Oertel MF, Schwedler M, Stein M, Wachter D, Scharbrodt W, Schmidinger A, et al. Cerebral energy failure after subarachnoid hemorrhage: the role of relative hyperglycolysis. Journal of clinical neuroscience : official journal of the Neurosurgical Society of Australasia. 2007 Oct;14(10):948-54. PubMed PMID: 17669657. 
DOI: 10.2478/romneu-2014-0043

32.Parkin M, Hopwood S, Jones DA, Hashemi P, Landolt $\mathrm{H}$, Fabricius $\mathrm{M}$, et al. Dynamic changes in brain glucose and lactate in pericontusional areas of the human cerebral cortex, monitored with rapid sampling on-line microdialysis: relationship with depolarisation-like events. Journal of cerebral blood flow and metabolism : official journal of the International Society of Cerebral Blood Flow and Metabolism. 2005 Mar;25(3):402-13. PubMed PMID: 15703701.

33.Rehncrona S, Hauge HN, Siesjo BK. Enhancement of iron-catalyzed free radical formation by acidosis in brain homogenates: differences in effect by lactic acid and $\mathrm{CO} 2$. Journal of cerebral blood flow and metabolism : official journal of the International Society of Cerebral Blood Flow and Metabolism. 1989 Feb;9(1):65-70. PubMed PMID: 2492027. Epub 1989/02/01. eng.

34.Siesjo BK, Wieloch T. Cerebral metabolism in ischaemia: neurochemical basis for therapy. British journal of anaesthesia. 1985 Jan;57(1):47-62. PubMed PMID: 3917676. Epub 1985/01/01. eng.

35.Smith ML, von Hanwehr R, Siesjo BK. Changes in extra- and intracellular $\mathrm{pH}$ in the brain during and following ischemia in hyperglycemic and in moderately hypoglycemic rats. Journal of cerebral blood flow and metabolism : official journal of the International Society of Cerebral Blood Flow and Metabolism. 1986 Oct;6(5):574-83. PubMed PMID: 3760041. Epub 1986/10/01. eng.

36.Statler KD, Janesko KL, Melick JA, Clark RSB, Jenkins LW, Kochanek PM. Hyperglycolysis is exacerbated after traumatic brain injury with fentanyl vs. isoflurane anesthesia in rats. Brain research. 2003;994(1):37-43.

37.Antonow-Schlorke I, Ebert M, Muller T, Schubert H, Gschanes A, Witte OW, et al. Glucose transporter proteins GLUT1 and GLUT3 like immunoreactivities in the fetal sheep brain are not reduced by maternal betamethasone treatment. Neuroscience letters. 2006 Aug 7;403(3):261-5. PubMed PMID: 16782269.

38.Nehlig A, Rudolf G, Leroy C, Rigoulot MA, Simpson IA, Vannucci SJ. Pentylenetetrazol-induced status epilepticus up-regulates the expression of glucose transporter mRNAs but not proteins in the immature rat brain. Brain research. 2006 Apr 12;1082(1):32-42. PubMed PMID: 16516869.

39.Vorbrodt AW, Dobrogowska DH, Tarnawski M. Immunogold study of interendothelial junctionassociated and glucose transporter proteins during postnatal maturation of the mouse blood-brain barrier. Journal of neurocytology. 2001 Aug;30(8):705-16. PubMed PMID: 12118158.

40.Tsukamoto H, Hamada Y, Wu D, Boado RJ, Pardridge WM. GLUT1 glucose transporter: differential gene transcription and mRNA binding to cytosolic and polysome proteins in brain and peripheral tissues. Brain research Molecular brain research. 1998 Jul 15;58(12):170-7. PubMed PMID: 9685631.

41.Vannucci SJ, Maher F, Simpson IA. Glucose transporter proteins in brain: delivery of glucose to neurons and glia. Glia. 1997 Sep;21(1):2-21. PubMed PMID: 9298843.

42.Vannucci SJ, Seaman LB, Brucklacher RM, Vannucci RC. Glucose transport in developing rat brain: glucose transporter proteins, rate constants and cerebral glucose utilization. Molecular and cellular biochemistry. 1994 Nov 23;140(2):177-84. PubMed PMID: 7898489.

43.Maher F, Vannucci SJ, Simpson IA. Glucose transporter proteins in brain. FASEB journal : official publication of the Federation of American Societies for Experimental Biology. 1994 Oct;8(13):1003-11. PubMed PMID: 7926364.

44.Goodman JR, Gamble D, Kay MM. Distribution and function of multiple anion transporter proteins in brain tumor cell lines in relation to glucose transport. Brain research bulletin. 1994;33(4):411-7. PubMed PMID: 8124579.

45.Kainulainen H, Schurmann A, Vilja P, Joost HG. Invivo glucose uptake and glucose transporter proteins GLUT1 and GLUT3 in brain tissue from streptozotocindiabetic rats. Acta physiologica Scandinavica. 1993 Oct;149(2):221-5. PubMed PMID: 8266811.

46.Maher F, Simpson IA, Vannucci SJ. Alterations in brain glucose transporter proteins, GLUT1 and GLUT3, in streptozotocin diabetic rats. Advances in experimental medicine and biology. 1993;331:9-12. PubMed PMID: 8333352.

47.Maher F, Vannucci S, Takeda J, Simpson IA. Expression of mouse-GLUT3 and human-GLUT3 glucose transporter proteins in brain. Biochemical and biophysical research communications. 1992 Jan 31;182(2):703-11. PubMed PMID: 1734877.

48.Huang Y, Lei L, Liu D, Jovin I, Russell R, Johnson RS, et al. Normal glucose uptake in the brain and heart requires an endothelial cell-specific HIF-1alphadependent function. Proceedings of the National 
Academy of Sciences of the United States of America. 2012 Oct 23;109(43):17478-83. PubMed PMID: 23047702. Pubmed Central PMCID: 3491491.

49.Godoy DA, Rabinstein A, Videtta W, Murillo-Cabezas F. Manejo óptimo de la glucemia en el paciente neurocrítico. Revista de neurologia. 2010;51:745-56.

50.Qutub AA, Hunt CA. Glucose transport to the brain: a systems model. Brain research Brain research reviews. 2005 Nov;49(3):595-617. PubMed PMID: 16269321.

51.Chih CP, Roberts Jr EL. Energy substrates for neurons during neural activity: a critical review of the astrocyteneuron lactate shuttle hypothesis. Journal of cerebral blood flow and metabolism : official journal of the International Society of Cerebral Blood Flow and Metabolism. 2003 Nov;23(11):1263-81. PubMed PMID: 14600433. Epub 2003/11/06. eng.

52.Forsyth R, Fray A, Boutelle M, Fillenz M, Middleditch C, Burchell A. A role for astrocytes in glucose delivery to neurons? Developmental neuroscience. 1996;18(56):360-70. PubMed PMID: 8940607. Epub 1996/01/01. eng.

53.Yarkov A, Montero S, Lemus M, Roces de AlvarezBuylla E, Alvarez-Buylla R. Arginine-vasopressin in nucleus of the tractus solitarius induces hyperglycemia and brain glucose retention. Brain research. 2001 Jun 1;902(2):212-22. PubMed PMID: 11384615.

54.Kum W, Zhu SQ, Ho SK, Young JD, Cockram CS. Effect of insulin on glucose and glycogen metabolism and leucine incorporation into protein in cultured mouse astrocytes. Glia. 1992;6(4):264-8. PubMed PMID: 1464458.

55.Bingham EM, Hopkins D, Smith D, Pernet A, Hallett $\mathrm{W}$, Reed L, et al. The role of insulin in human brain glucose metabolism: an 18fluoro-deoxyglucose positron emission tomography study. Diabetes. 2002 Dec;51(12):3384-90. PubMed PMID: 12453890.

56.Marty N, Dallaporta M, Thorens B. Brain glucose sensing, counterregulation, and energy homeostasis. Physiology (Bethesda, Md). 2007 Aug;22:241-51. PubMed PMID: 17699877. Epub 2007/08/19. eng.

57.Minokoshi Y, Alquier T, Furukawa N, Kim YB, Lee A, Xue B, et al. AMP-kinase regulates food intake by responding to hormonal and nutrient signals in the hypothalamus. Nature. 2004 Apr 1;428(6982):569-74. PubMed PMID: 15058305. Epub 2004/04/03. eng. 58.Cataldo AM, Broadwell RD. Cytochemical identification of cerebral glycogen and glucose-6- phosphatase activity under normal and experimental conditions. II. Choroid plexus and ependymal epithelia, endothelia and pericytes. Journal of neurocytology. 1986 Aug;15(4):511-24. PubMed PMID: 3018177.

59.Sickmann HM, Waagepetersen HS, Schousboe A, Benie AJ, Bouman SD. Brain glycogen and its role in supporting glutamate and GABA homeostasis in a type 2 diabetes rat model. Neurochemistry international. 2012 Feb;60(3):267-75. PubMed PMID: 22244844.

60.Godoy DA, Di Napoli M, Biestro A, Lenhardt R. Perioperative glucose control in neurosurgical patients. Anesthesiology research and practice. 2012;2012:690362. PubMed PMID: 22400022. Pubmed Central PMCID: 3286889.

61.Godoy DA, Di Napoli M, Rabinstein AA. Treating hyperglycemia in neurocritical patients: benefits and perils. Neurocritical care. 2010 Dec;13(3):425-38. PubMed PMID: 20652767.

62.Nylen ES, Muller B. Endocrine changes in critical illness. Journal of intensive care medicine. $2004 \mathrm{Mar}-$ Apr;19(2):67-82. PubMed PMID: 15070518. Epub 2004/04/09. eng.

63.McCowen KC, Malhotra A, Bistrian BR. Stressinduced hyperglycemia. Critical care clinics. 2001 Jan;17(1):107-24. PubMed PMID: 11219223. Epub 2001/02/24. eng.

64.Gearhart MM, Parbhoo SK. Hyperglycemia in the critically ill patient. AACN clinical issues. 2006 JanMar;17(1):50-5. PubMed PMID: 16462409.

65.Robinson LE, van Soeren MH. Insulin resistance and hyperglycemia in critical illness: role of insulin in glycemic control. AACN clinical issues. 2004 JanMar;15(1):45-62. PubMed PMID: 14767364. Epub 2004/02/10. eng.

66.Garg R, Chaudhuri A, Munschauer F, Dandona P. Hyperglycemia, insulin, and acute ischemic stroke: a mechanistic justification for a trial of insulin infusion therapy. Stroke; a journal of cerebral circulation. 2006 Jan;37(1):267-73. PubMed PMID: 16306459. Epub 2005/11/25. eng.

67.McCormick MT, Muir KW, Gray CS, Walters MR. Management of hyperglycemia in acute stroke: how, when, and for whom? Stroke; a journal of cerebral circulation. 2008 Jul;39(7):2177-85. PubMed PMID: 18436889. Epub 2008/04/26. eng.

68.Harada S, Fujita-Hamabe W, Tokuyama S. Effect of orexin-A on post-ischemic glucose intolerance and 
DOI: 10.2478/romneu-2014-0043

neuronal damage. Journal of pharmacological sciences. 2011;115(2):155-63. PubMed PMID: 21258173. Epub 2011/01/25. eng.

69.Allport LE, Butcher KS, Baird TA, MacGregor L, Desmond PM, Tress BM, et al. Insular cortical ischemia is independently associated with acute stress hyperglycemia. Stroke; a journal of cerebral circulation. 2004 Aug;35(8):1886-91. PubMed PMID: 15192241. Epub 2004/06/12. eng.

70.Simpson IA, Appel NM, Hokari M, Oki J, Holman GD, Maher F, et al. Blood-brain barrier glucose transporter: effects of hypo- and hyperglycemia revisited. Journal of neurochemistry. 1999 Jan;72(1):238-47. PubMed PMID: 9886075. Epub 1999/01/14. eng.

71.Tomlinson DR, Gardiner NJ. Glucose neurotoxicity. Nature reviews Neuroscience. 2008 Jan;9(1):36-45. PubMed PMID: 18094705.

72.Molz S, Decker H, Oliveira IJ, Souza DO, Tasca CI. Neurotoxicity induced by glutamate in glucose-deprived rat hippocampal slices is prevented by GMP. Neurochemical research. 2005 Jan;30(1):83-9. PubMed PMID: 15756936.

73.Annetta MG, Ciancia M, Soave M, Proietti R. Diabetic and nondiabetic hyperglycemia in the ICU. Current Anaesthesia \& Critical Care. 2006;17(6):385-90.

74.Shah GN, Price TO, Banks WA, Morofuji Y, Kovac A, Ercal $\mathrm{N}$, et al. Pharmacological Inhibition of Mitochondrial Carbonic Anhydrases Protects Mouse Cerebral Pericytes from High Glucose-Induced Oxidative Stress and Apoptosis. The Journal of pharmacology and experimental therapeutics. 2012 Dec 17. PubMed PMID: 23249625. Epub 2012/12/20. Eng.

75.Higashi Y, Noma K, Yoshizumi $M$, Kihara $Y$. Endothelial function and oxidative stress in cardiovascular diseases. Circulation journal : official journal of the Japanese Circulation Society. 2009 Mar;73(3):411-8. PubMed PMID: 19194043.

76.Anderson RE, Tan WK, Martin HS, Meyer FB. Effects of glucose and $\mathrm{PaO} 2$ modulation on cortical intracellular acidosis, NADH redox state, and infarction in the ischemic penumbra. Stroke; a journal of cerebral circulation. 1999 Jan;30(1):160-70. PubMed PMID: 9880405.

77.Wang JW, Liu JY, Yan PH, Wang J, Wang H. [Effects of lactate on cell injury in primary cultures of rat cortical neurons during hypoxia/reoxygenation]. Zhongguo ying yong sheng li xue za zhi $=$ Zhongguo yingyong shenglixue zazhi $=$ Chinese journal of applied physiology. 2008 Nov;24(4):434-8. PubMed PMID: 21158145. Epub 2008/11/01. chi.

78.Wu G, Bao X, Xi G, Keep RF, Thompson BG, Hua Y. Brain injury after intracerebral hemorrhage in spontaneously hypertensive rats. Journal of neurosurgery. 2011 Jun;114(6):1805-11. PubMed PMID: 21294617. Pubmed Central PMCID: PMC3107381. Epub 2011/02/08. eng.

79.Krafft PR, Bailey EL, Lekic T, Rolland WB, Altay O, Tang J, et al. Etiology of stroke and choice of models. International journal of stroke : official journal of the International Stroke Society. 2012 Jul;7(5):398-406. PubMed PMID: 22712741. Epub 2012/06/21. eng.

80.Keep RF, Hua Y, Xi G. Intracerebral haemorrhage: mechanisms of injury and therapeutic targets. The Lancet Neurology. 2012 8//;11(8):720-31.

81.Chiu CD, Chen TY, Chin LT, Shen CC, Huo J, Ma SY, et al. Investigation of the effect of hyperglycemia on intracerebral hemorrhage by proteomic approaches. Proteomics. 2012 Jan;12(1):113-23. PubMed PMID: 22065606. Epub 2011/11/09. eng.

82.Helbok R, Schmidt JM, Kurtz P, Hanafy KA, Fernandez L, Stuart RM, et al. Systemic glucose and brain energy metabolism after subarachnoid hemorrhage. Neurocritical care. 2010 Jun;12(3):317-23. PubMed PMID: 20135362. Epub 2010/02/06. eng.

83.Perantie DC, Wu J, Koller JM, Lim A, Warren SL, Black KJ, et al. Regional brain volume differences associated with hyperglycemia and severe hypoglycemia in youth with type 1 diabetes. Diabetes care. 2007 Sep;30(9):2331-7. PubMed PMID: 17575089. Epub 2007/06/19. eng.

84.Bingham EM, Dunn JT, Smith D, Sutcliffe-Goulden J, Reed LJ, Marsden PK, et al. Differential changes in brain glucose metabolism during hypoglycaemia accompany loss of hypoglycaemia awareness in men with type 1 diabetes mellitus. An [11C]-3-O-methyl-D-glucose PET study. Diabetologia. 2005 Oct;48(10):2080-9. PubMed PMID: 16143864. Epub 2005/09/07. eng.

85.Berbel-Garcia A, Porta-Etessam J, Martinez-Salio A, Ballesta F, Saiz-Diaz RA, Perez-Martinez DA, et al. [Transient cerebral oedema associated to hypoglycaemia]. Revista de neurologia. 2004 Dec 115;39(11):1030-3. PubMed PMID: 15597265. Epub 2004/12/15. Edema cerebral transitorio asociado a hipoglucemia. spa. 
86.MacLeod KM, Gold AE, Ebmeier KP, Hepburn DA, Deary IJ, Goodwin GM, et al. The effects of acute hypoglycemia on relative cerebral blood flow distribution in patients with type I (insulin-dependent) diabetes and impaired hypoglycemia awareness. Metabolism: clinical and experimental. 1996 Aug;45(8):974-80. PubMed PMID: 8769355. Epub 1996/08/01. eng.

87.Choi IY, Seaquist ER, Gruetter R. Effect of hypoglycemia on brain glycogen metabolism in vivo. Journal of neuroscience research. 2003 Apr 1;72(1):25-32. PubMed PMID: 12645076. Pubmed Central PMCID: PMC1471897. Epub 2003/03/20. eng.

88.Oz G, Kumar A, Rao JP, Kodl CT, Chow L, Eberly LE, et al. Human brain glycogen metabolism during and after hypoglycemia. Diabetes. 2009 Sep;58(9):1978-85. PubMed PMID: 19502412. Pubmed Central PMCID: PMC2731528. Epub 2009/06/09. eng.

89.Oz G, Henry PG, Seaquist ER, Gruetter R. Direct, noninvasive measurement of brain glycogen metabolism in humans. Neurochemistry international. 2003 SepOct;43(4-5):323-9. PubMed PMID: 12742076. Epub 2003/05/14. eng.

90.Feuerstein D, Manning A, Hashemi P, Bhatia R, Fabricius M, Tolias C, et al. Dynamic metabolic response to multiple spreading depolarizations in patients with acute brain injury: an online microdialysis study. Journal of cerebral blood flow and metabolism : official journal of the International Society of Cerebral Blood Flow and Metabolism. 2010 Jul;30(7):1343-55. PubMed PMID: 20145653. Pubmed Central PMCID: 2949215.

91.Samiullah S, Qasim R, Imran S, Mukhtair J. Frequency of stress hyperglycaemia and its' influence on the outcome of patients with spontaneous intracerebral haemorrhage. JPMA The Journal of the Pakistan Medical Association. 2010 Aug;60(8):660-3. PubMed PMID: 20726199. Epub 2010/08/24. eng.

92.Bamford J, Sandercock P, Dennis M, Burn J, Warlow C. A prospective study of acute cerebrovascular disease in the community: the Oxfordshire Community Stroke Project--1981-86. 2. Incidence, case fatality rates and overall outcome at one year of cerebral infarction, primary intracerebral and subarachnoid haemorrhage. Journal of neurology, neurosurgery, and psychiatry. 1990
Jan;53(1):16-22. PubMed PMID: 2303826. Pubmed Central PMCID: PMC1014091. Epub 1990/01/01. eng. 93.Bamford J, Sandercock P, Dennis M, Warlow C, Jones L, McPherson K, et al. A prospective study of acute cerebrovascular disease in the community: the Oxfordshire Community Stroke Project 1981-86. 1. Methodology, demography and incident cases of firstever stroke. Journal of neurology, neurosurgery, and psychiatry. 1988 Nov;51(11):1373-80. PubMed PMID: 3266234. Pubmed Central PMCID: PMC1032805. Epub 1988/11/01. eng.

94.Douglas MA, Haerer AF. Long-term prognosis of hypertensive intracerebral hemorrhage. Stroke; a journal of cerebral circulation. 1982 Jul-Aug;13(4):488-91. PubMed PMID: 7101349.

95.Helweg-Larsen S, Sommer W, Strange P, Lester J, Boysen G. Prognosis for patients treated conservatively for spontaneous intracerebral hematomas. Stroke; a journal of cerebral circulation. 1984 Nov-Dec;15(6):10458. PubMed PMID: 6506116.

96.Kojima S, Omura T, Wakamatsu W, Kishi M, Yamazaki T, Iida M, et al. Prognosis and disability of stroke patients after 5 years in Akita, Japan. Stroke; a journal of cerebral circulation. 1990 Jan;21(1):72-7. PubMed PMID: 2300993. Epub 1990/01/01. eng. 97.Chi A, Lissauer ME, Kirchoffner J, Scalea TM, Johnson SB. Effect of glycemic state on hospital mortality in critically ill surgical patients. The American surgeon. 2011 Nov;77(11):1483-9. PubMed PMID: 22196662. Epub 2011/12/27. eng.

98.Obiako OR, Oparah SK, Ogunniyi A. Prognosis and outcome of acute stroke in the University College Hospital Ibadan, Nigeria. Nigerian journal of clinical practice. 2011 Jul-Sep;14(3):359-62. PubMed PMID: 22037085. Epub 2011/11/01. eng.

99.Di Napoli M, Godoy DA, Campi V, del Valle M, Pinero G, Mirofsky M, et al. C-reactive protein level measurement improves mortality prediction when added to the spontaneous intracerebral hemorrhage score. Stroke; a journal of cerebral circulation. 2011 May;42(5):1230-6. PubMed PMID: 21474813. Epub 2011/04/09. eng. 